\title{
The system $\mathrm{CaO}-\mathrm{MgO}-\mathrm{FeO}-\mathrm{SiO}_{2}$ and its bearing on the origin of ultrabasic and basic rocks.
}

\author{
By Peter J. Wyldie, B.Sc., Ph.D.
}

School of Chemistry, University of Leeds.

[Read 28 January 1960.]

Summary. Experimental data in the system $\mathrm{CaO}-\mathrm{MgO}-\mathrm{FeO}-\mathrm{SiO}_{2}$ suggest that there may be a plateau on the liquidus and solidus of the multicomponent system basalt-peridotite. If this is so, fusion of peridotite would produce only basaltic magmas over a wide temperature range; when the temperature reached a value such that the liquid crossed the threshold of the plateau, there would be a rapid increase in the amount of fusion for small temperature increases, with the formation of picritic magmas; basaltic magmas containing suspended forsteritic olivine crystals could dissolve them if the temperature rose slightly above that of the plateau threshold; a high proportion of a pieritic magma would erystallize in a small temperature interval, with the precipitation of forsteritic olivine that was only slightly zoned. These possibilities are compared with current theories, and it is concluded that several petrological axioms may require critical re-examination. An experimental procedure is outlined to determine the shape of the liquidus and solidus in the basalt-peridotite system.

$\mathrm{M}$

ANY ultrabasic rocks are composed almost entirely of the six oxides $\mathrm{SiO}_{2}, \mathrm{Al}_{2} \mathrm{O}_{3}, \mathrm{Fe}_{2} \mathrm{O}_{3}, \mathrm{FeO}, \mathrm{MgO}$, and $\mathrm{CaO}$. Phase relations in systems involving these oxides have been studied with special reference to steel plant refractories and slags (Osborn, 1954) and, although the compositions of interest to the steel industry do not always coincide with those of interest to petrologists, parts of the systems studied in most detail correspond closely to the compositions of some ultrabasic rocks. Of particular interest is Ricker's (1952) study of the system $\mathrm{CaO}-\mathrm{MgO}$ $\mathrm{FeO}-\mathrm{SiO}_{2}$.

The term 'ultrabasic' embraces many different rock types, which occur in a wide variety of field and petrographic associations. The present communication is concerned only with the origin of olivine-rich rocks, but even with this limitation there remain to be considered many different field associations. The following discussion is most relevant to rocks that occur in a volcanic association, e.g. the minor intrusions of picrite and peridotite in Skye (Harker, 1904; Bowen, 1928; Drever and Johnston, 1958), the sheets of picrite on Ubekendt Ejland, West Green- 
land (Drever, 1956), and many olivine basalts of the world. Field and petrographic studies of picritic rocks have cast doubt on the adequacy of the hypothesis of olivine accumulation from basaltic magma to explain their origin (Drever, 1952, 1956; Drever and Johnston, 1958; Wyllie, $1958 a$ ). There is much evidence indicating that accumulation of olivine crystals does occur during the crystallization of basaltic magma, but this does not mean that olivine-rich and ultrabasic rocks may not be derived from other sources, and by other means. In view of the complexity of magmas and magmatic processes, it appears unjustifiable to erect a single hypothesis for the origin of all ultrabasic rocks in their many and varied occurrences.

Experimental studies demand a very high temperature for the existence of ultrabasic liquids, which is one reason why many petrologists classify all ultrabasic rocks as accumulates (Bowen, 1928). This prompted a search of the available phase-equilibrium data for alternative possibilities.

Phase equilibrium studies and the melting temperatures of olivine-rich rocks.

Reviews of ultrabasic rocks generally refer to their low intrusion temperatures. According to Turner and Verhoogen (1951, p. 243) the intrusion temperature of peridotites in the orogenic zones 'is commonly, if not always, of the order of a few hundred degrees'. There is a tendency to overlook the fact that other ultrabasic rocks show evidence of higher intrusion temperatures. For instance, some of the peridotites in Skye were hotter than gabbros when emplaced (Harker, 1904, 1909), and some of the minor intrusions of picrite on Soay were apparently emplaced at relatively high temperatures (Wyllie, 1958a, 1958b). There appears to be no field evidence to support the contention of Vogt (1922) that dunites and peridotites were emplaced as very hot liquid magmas with temperatures near $1600^{\circ} \mathrm{C}$.

Forsterite melts at $1890^{\circ} \mathrm{C}$, and available experimental data suggest that ultrabasic liquids, rich in forsterite, can exist only at very high temperatures. Vogt suggested that addition of fayalite to forsterite might cause marked lowering of liquidus temperatures, but subsequent study of the system $\mathrm{MgO}-\mathrm{FeO}-\mathrm{SiO}_{2}$ (Bowen and Schairer, 1935) proved that a temperature of $1800^{\circ} \mathrm{C}$. was required for the complete melting of olivine up to $\mathrm{Fo}_{80} \mathrm{Fa}_{20}$ in composition. Osborn and Tait (1952) found that in the system diopside-anorthite-forsterite, although some liquid. developed at rather low temperatures $\left(1270^{\circ} \mathrm{C}\right.$.) for mixtures rich in forsterite, the amount of liquid remained very small until high tempera- 
tures were reached. Harker (1909) believed that many ultrabasic rocks were emplaced as liquid magmas, and that the addition of volatiles would aid the liquefaction of accumulated olivine crystals at moderate temperatures (oral communication to Bowen, 1928, p. 166), but he realized the difficulty of visualizing a process whereby volatiles could be added to a largely crystalline mass. In order to explain certain field relationships of peridotites in orogenic zones, Hess (1938) postulated that these rocks were emplaced, at low temperatures, as aqueous ultrabasic liquids derived by fusion of the ultrabasic substratum. Investigation of the system $\mathrm{MgO}-\mathrm{SiO}_{2}-\mathrm{H}_{2} \mathrm{O}$ (Bowen and Tuttle, 1949) does not support this view. No liquid phase was developed below $1000^{\circ} \mathrm{C}$. at pressures up to $30000 \mathrm{lb} . / \mathrm{sq}$. in., and the effect of water vapour on the melting relations of ultrabasic compositions remains uncertain. Bowen and Tuttle concluded that intrusion of a crystal mush was the most likely mechanism for the emplacement of ultrabasic rocks. Hess (1955) pointed out the difficulties inherent in this mechanism of intrusion, and he believes that the field evidence for magmatic origin should take precedence over experimental evidence.

Ricker (1952) discovered that the addition to forsterite of calcium orthosilicate (larnite) as well as fayalite does cause a marked lowering of liquidus temperatures. Since olivine-rich rocks (dunites excepted) contain appreciable amounts of $\mathrm{CaO}$ and $\mathrm{FeO}$ it seems that they could exist as liquids at temperatures lower than previously suspected from experimental data. Liquidus temperatures in relevant parts of the system $\mathrm{CaO}-\mathrm{MgO}-\mathrm{FeO}-\mathrm{SiO}_{2}$ are nevertheless much higher than estimated intrusion temperatures of ultrabasic rocks.

\section{$\mathrm{CaO}-\mathrm{MgO}-\mathrm{FeO}-\mathrm{SiO}_{2}$ and related systems.}

The phase relations in a quaternary system may be represented by a tetrahedron whose four corners represent the four components. Fig. 1 shows the system $\mathrm{CaO}-\mathrm{MgO}-\mathrm{FeO}-\mathrm{SiO}_{2}$; only selected compounds and joins are illustrated. For olivine-rich rocks, the orthosilicate join is of greatest interest. Phase relationships for this join were determined by Ricker (1952); primary crystallization fields and isotherms for the liquidus and solidus surfaces are reproduced in fig. $2 a$. Tie-lines for coexisting liquids and crystals were not determined, but the position of the solidus was located in parts of the system and sketched approximately elsewhere (dotted lines). Three primary phase fields appear on the join, and the field of olivine is by far the largest.

There is a temperature valley on both liquidus and solidus surfaces of 
the olivine field, extending initially from $2 \mathrm{MgO}^{\mathrm{SiO}} \mathrm{S}_{2}$ (forsterite) towards $\mathrm{CaO} . \mathrm{FeO} \cdot \mathrm{SiO}_{2}$. In the central part of the diagram, the valley opens out into a plateau of considerable extent, and from this plateau the valley

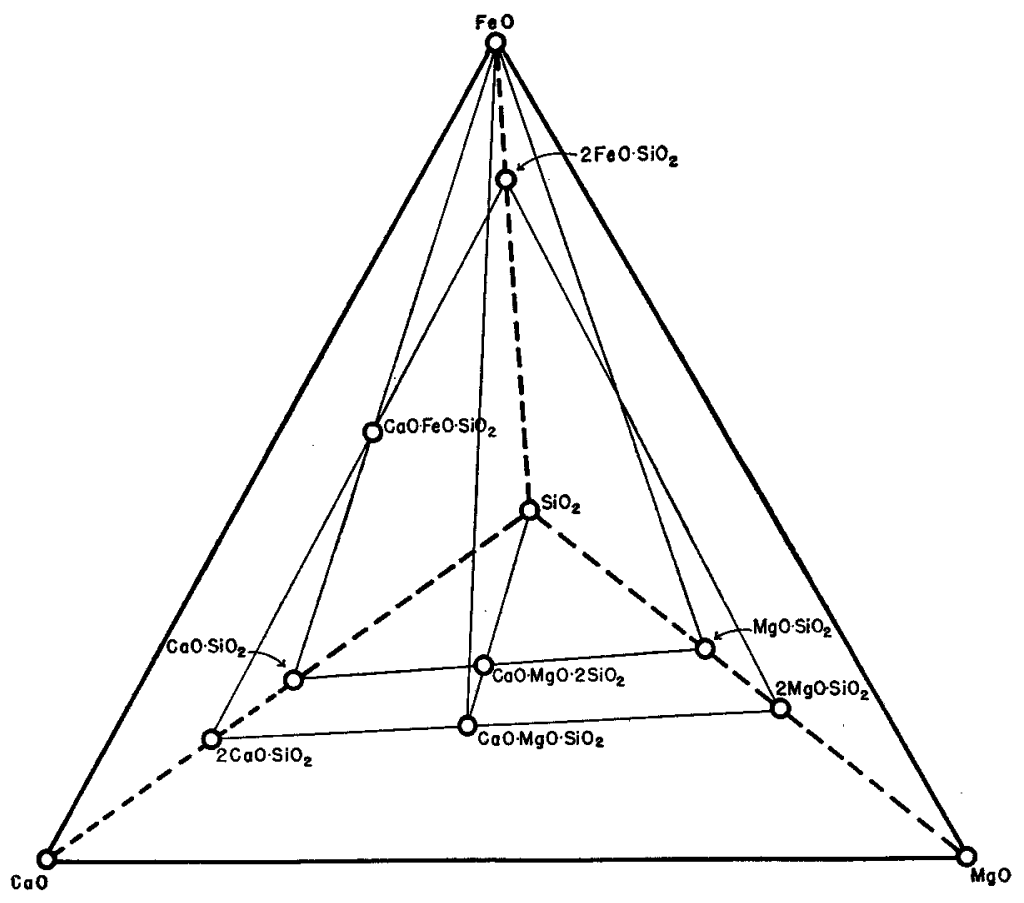

FIG. 1. Tetrahedron representing the quaternary system $\mathrm{CaO}-\mathrm{MgO}-\mathrm{FeO}-\mathrm{SiO}_{2}$. Compounds are plotted in weight $\%$ of the four components. Lighter lines bound triangular joins (after Ricker, 1952).

continues towards the temperature minimum on the join $\mathrm{CaO} . \mathrm{FeO}^{-\mathrm{SiO}_{2}-}$ $2 \mathrm{FeO} . \mathrm{SiO}_{2}$. The rapid lowering of liquidus temperatures produced by the addition of $\mathrm{CaO} . \mathrm{FeO} . \mathrm{SiO}_{2}$ to $2 \mathrm{MgO} \mathrm{SiO}_{2}$ is well illustrated by the section across the olivine join shown in fig. $2 b$. In this section, compositions containing almost 60 weight $\%$ of forsterite are completely liquid at $1500^{\circ} \mathrm{C}$. The effect of adding $\mathrm{CaO}$ and $\mathrm{Al}_{2} \mathrm{O}_{3}$ to forsterite is less marked; in the system diopside-anorthite-forsterite (Osborn and Tait, 1952), compositions containing 60 weight $\%$ of forsterite are completely liquid only above $1600^{\circ} \mathrm{C}$, and in the binary system $2 \mathrm{MgO}^{\circ} \mathrm{SiO}_{2}$ a temperature of about $1730^{\circ} \mathrm{C}$. would be required to liquify a composition containing 60 weight $\%$ forsterite (fig. $2 a$ ). 

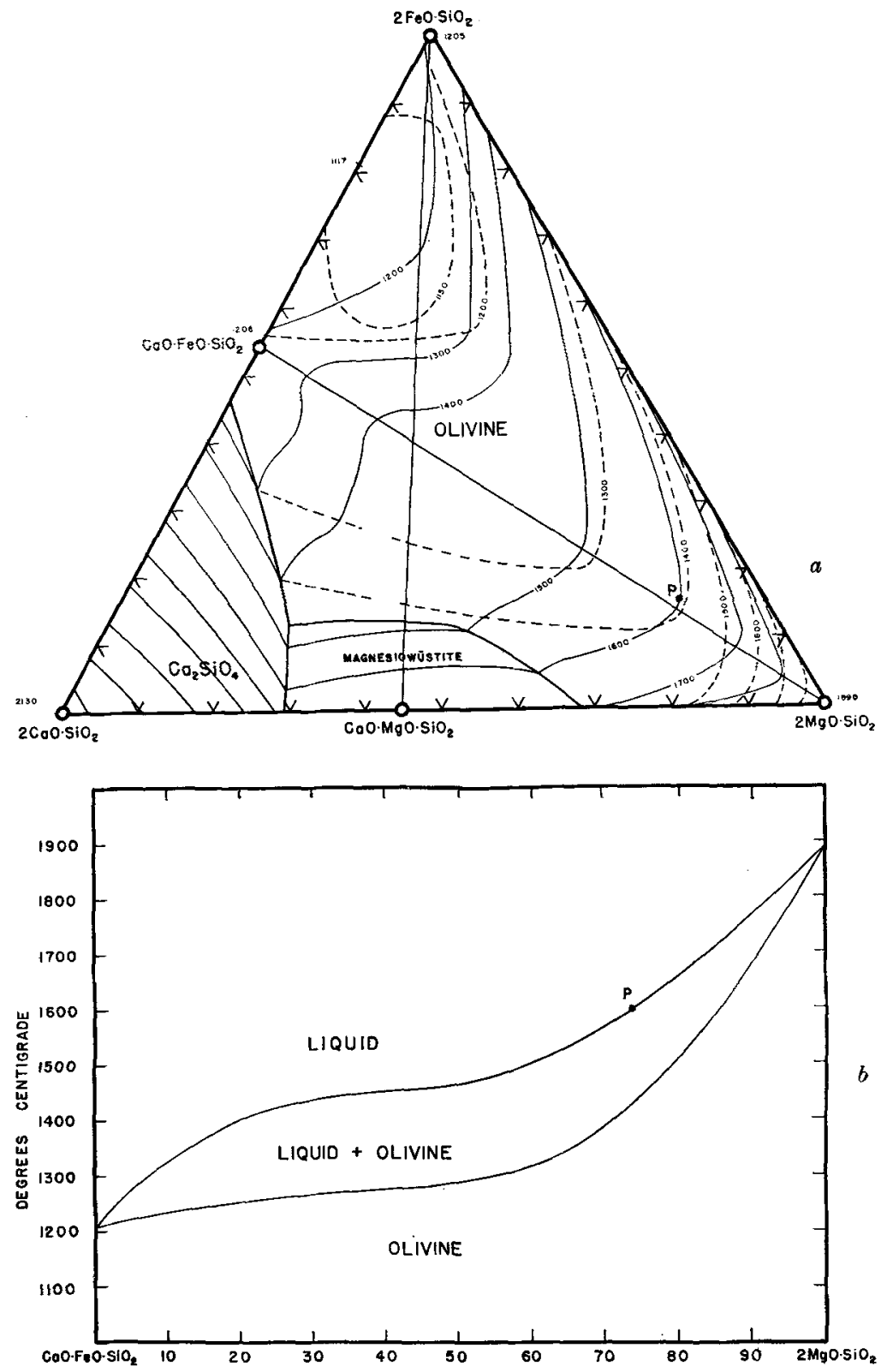

Fig. 2. a. Equilibrium diagram for the olivine join in the quaternary system $\mathrm{CaO}-\mathrm{MgO}-\mathrm{FeO}-\mathrm{SiO}_{\mathrm{g}}$. Heary lines are boundary curves; light lines are isotherms; light dashed lines are solidus isotherms in the olivine field. $b$. Liquidus and solidus intersections for the join $2 \mathrm{MgO} . \mathrm{SiO}_{2}-\mathrm{CaO} . \mathrm{FeO} . \mathrm{SiO}_{2}$. This section is not a binary system. $P$ is the point representing the composition of an analysed picrite: all $\mathrm{MgO}, \mathrm{FeO}$, and $\mathrm{CaO}$ were calculated as normative orthosilicate and recalculated to $100 \%$ (both diagrams after Ricker, 1952). 
The existence of such a large plateau on both liquidus and solidus surfaces of the orthosilicate join results in some rather unusual crystallization and fusion phenomena. With cooling, the composition of a liquid on the liquidus plateau could change considerably while the composition of the crystallizing olivine would change only slightly and, with heating, the composition of the crystalline material on the solidus plateau could change considerably while that of the liquid developed by fusion would change only slightly. These conditions can be illustrated by a section across the centre of the plateau (fig. 2b). This join is not a binary system because tie-lines connecting coexisting liquids and olivines do not lie in the plane of the section, but there is evidence that the tie-lines intersect the plane in quite small angles. The situation is further complicated by the fact that the orthosilicate plane itself is not ternary. However, for the purpose of discussion the join may be treated as a binary system of the type with complete solid solution between the end-members. The changing composition of olivine in fig. $2 b$ then involves a variation in lime content. Accurate determination of the quaternary tie-lines between liquid and olivine would probably reveal a low content of lime in all crystals; olivines precipitated from basaltic magmas rarely contain more than 1 weight $\% \mathrm{CaO}$. Persistence of the plateau over a large part of the olivine field confirms the general applicability of the relations described below.

Consider a mixture in fig. $2 b$ with composition forsterite $58 \%$ (58Fo). This would be completely liquid above $1500^{\circ} \mathrm{C}$, and at $1500^{\circ} \mathrm{C}$. crystals of 79Fo would appear. With further cooling, more olivine would be precipitated and the liquid composition would change down the liquidus surface; provided equilibrium were maintained, the composition of the crystals would change down the solidus surface. At $1400^{\circ} \mathrm{C}$, about $75 \%$ of the liquid would have crystallized and that remaining would have the composition $19 \mathrm{Fo}$; the crystals would be $71.5 \mathrm{Fo}$. At $1310^{\circ} \mathrm{C}$., the last trace of liquid (composition $9 \mathrm{Fo}$ ) would crystallize, leaving only olivine crystals, $58 \mathrm{Fo}$. Thus, a change in temperature from $1500^{\circ} \mathrm{C}$. to $1400^{\circ} \mathrm{C}$. would cause the liquid to change composition from $58 \mathrm{Fo}$ to $19 \mathrm{Fo}$, while $75 \%$ of it crystallized, and the olivine precipitated from it would change only from $79 \mathrm{Fo}$ to $71.5 \mathrm{Fo}$; and a change in temperature from $1400^{\circ} \mathrm{C}$. to $1310^{\circ} \mathrm{C}$. would cause the remaining $25 \%$ of liquid to change composition from $19 \mathrm{Fo}$ to $9 \mathrm{Fo}$ (the last trace of liquid), while the olivine crystallizing changed from $71.5 \mathrm{Fo}$ to $58 \mathrm{Fo}$. Similarly, if a crystalline charge with composition $58 \mathrm{Fo}$ were heated, the first trace of liquid, with composition $9 \mathrm{Fo}$, would appear at $1310^{\circ} \mathrm{C}$. In the 
temperature interval $1310^{\circ} \mathrm{C}$. to $1400^{\circ} \mathrm{C}$. about $25 \%$ of the charge would melt, and the liquid developed would change composition from $9 \mathrm{Fo}$ to $19 \mathrm{Fo}$, while the olivine would change from $58 \mathrm{Fo}$ to $71.5 \mathrm{Fo}$. In the temperature interval $1400^{\circ} \mathrm{C}$. to $1500^{\circ} \mathrm{C}$. the remaining $75 \%$ of the solid would melt, the liquid changing in composition from $19 \mathrm{Fo}$ to $58 \mathrm{Fo}$, while the olivine changed from $71 \cdot 5 \mathrm{Fo}$ to $79 \mathrm{Fo}$ (the last crystal to melt).

Rocks may be projected on to the orthosilicate join by allocating all the $\mathrm{CaO}, \mathrm{MgO}$, and $\mathrm{FeO}$ in an analysis to normative orthosilicates, and recalculating to $100 \%$. If all available analyses of basic and picritic rocks for the Skye group of minor intrusions are projected on to the orthosilicate join in this way (fig. 3), they extend across the plateau from $P$ to the $1400^{\circ} \mathrm{C}$. isotherm (fig. $2 a$ ), and they are not far removed from

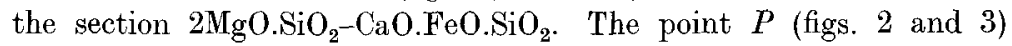
represents a picrite sill (Sill 1, Drever and Johnston, 1958; Wyllie, $1958 a$ ) composed of 61 modal \% olivine, $22 \%$ plagioclase, $14 \%$ clinopyroxene, and $3 \%$ spinel and serpentine. The compositional trend of the plotted rocks is shown by the curved line extending from $P$ (fig. 3 ). The average magma types of the Hebrides (Turner and Verhoogen, 1951, p. 193) and the hypothetical parent magma of the Rhum layered intrusion (Brown, 1956) are plotted for comparison. The numbers alongside the points give values for the ratio $\left(\mathrm{FeO}+\mathrm{Fe}_{2} \mathrm{O}_{3}\right) /\left(\mathrm{FeO}+\mathrm{Fe}_{2} \mathrm{O}_{3}+\mathrm{MgO}\right)$.

The picrite $P$ contains a small excess of $\mathrm{SiO}_{2}$ over that required to convert the $\mathrm{CaO}, \mathrm{MgO}$, and $\mathrm{FeO}$ to orthosilicate, and a point representing its position within the quaternary tetrahedron therefore lies between the orthosilicate join and the $\mathrm{SiO}_{2}$ corner (fig. 1). Basaltic liquids contain a fairly large excess of $\mathrm{SiO}_{2}$ over that required to convert all $\mathrm{CaO}, \mathrm{MgO}$, and $\mathrm{FeO}$ to orthosilicate, and points representing basalts within the tetrahedron are therefore quite far displaced from the orthosilicate join towards the $\mathrm{SiO}_{2}$ corner. Within the quaternary tetrahedron, therefore, the trend line projected in fig. 3 runs obliquely from the orthosilicate join towards the $\mathrm{SiO}_{2}$ corner of the tetrahedron.

The plateau feature persists on liquidus surfaces near the metasilicate join, e.g. on the join $\mathrm{CaO}_{\mathrm{SiO}}-\mathrm{MgO} . \mathrm{SiO}_{2}-\mathrm{FeO}$ (fig. 1), and here the variation of liquidus temperature over the whole join is less than that over the orthosilicate join (Ricker, 1952). Fairly level areas persist also on liquidus surfaces in the system $\mathrm{CaO}-\mathrm{MgO}-\mathrm{SiO}_{2}$, and on the 5,10 , and $15 \% \mathrm{Al}_{2} \mathrm{O}_{3}$ planes of the system $\mathrm{CaO}-\mathrm{MgO}-\mathrm{Al}_{2} \mathrm{O}_{3}-\mathrm{SiO}_{2}$ (Osborn et al., 1954). The level surfaces extend from the forsterite field across the field of pyroxene, with liquidus temperatures between $1400^{\circ} \mathrm{C}$. and $1300^{\circ} \mathrm{C}$., and on the $15 \% \mathrm{Al}_{2} \mathrm{O}_{3}$ plane the level area extends across the primary 
fields of pyroxene and anorthite. There are obvious parallels between this variation and that between ultrabasic and basic rocks.

When they are plotted in terms of normative orthosilicate, the Skye rocks, ranging in composition from picrite to basalt, lie close to the

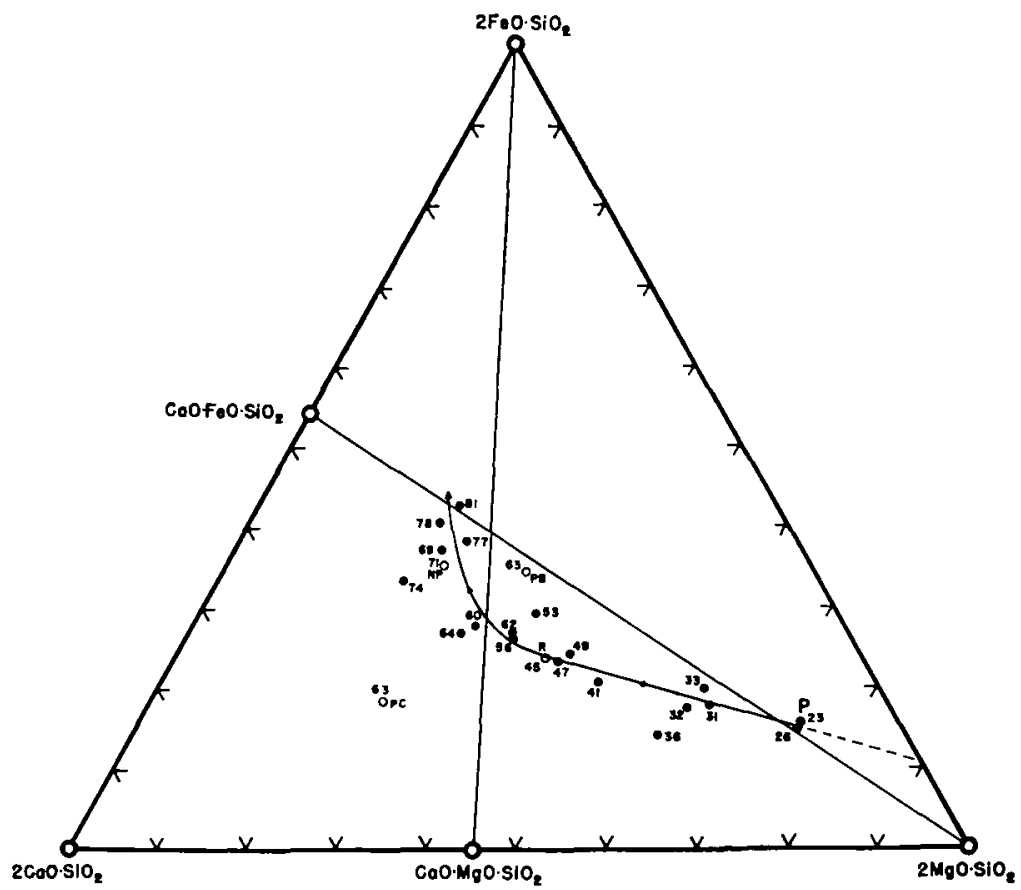

Fig. 3. Analyses of basic to ultrabasic rocks of the skye region projected on to the orthosilicate join of the system ( $\mathrm{aO}\left(\mathrm{O}-\mathrm{MgO}-\mathrm{FeO}_{-} \mathrm{SiO}\right.$. 'The open circles represent the average plateau basalt (PB), non-porphyritic central magma type (NP), porphyritic central magma type (P()), and the hypothetical parent magma of the Rhum layered intrusion $(\mathrm{R})$. The numbers give the values of the ratio $\left(\mathrm{Fe}()+\mathrm{Fe}_{2} \mathrm{O}_{3}\right)$ / $\left(\mathrm{FeO}-\mathrm{Fe}_{2} \mathrm{O}_{3} \cdot \mathrm{MgO}\right)$ for each rock. The analyses are taken from Harker, 1904; Drever and Johnston, 1958; and Wyllie, 1958a. The line through the points is a projection of the chemical variation of the rocks from within the tetrahedron (fig. 1) on to the orthosilicate plane.

liquidus of the section illustrated in fig. $2 b$. Furthermore, the plateau feature appears to persist in those parts of the system $\mathrm{CaO}-\mathrm{MgO}$ FeO$\mathrm{Al}_{2} \mathrm{O}_{3} \quad \mathrm{SiO}_{2}$ that are chemically related to these rocks. If a similar plateau exists on the liquidus between ultrabasic and basic rock compositions in the complex multicomponent system required to represent them completely, the patterns of fusion and crystallization described above for the join $2 \mathrm{MgO} . \mathrm{SiO}_{2}-\mathrm{CaO} . \mathrm{FeO} . \mathrm{SiO}_{2}$ (fig. 2b) could occur during certain 
petrological processes. The petrological deductions are speculative, because the phase equilibrium relations are tentative in many parts of the systems discussed, and comparison between the synthetic systems and rocks was qualitative only. However, their implications are of sufficient interest to justify their further consideration.

If, in fig. $2 b$, the composition range $10 \mathrm{Fo}$ to $20 \mathrm{Fo}$ is equated to basalts, and the range $50 \mathrm{Fo}$ to $80 \mathrm{Fo}$ is equated to picrites and peridotites, then compositions on the liquidus plateau between $20 \mathrm{Fo}$ and $50 \mathrm{Fo}$ would represent rocks ranging from olivine basalt to picrite (compare figs. 2 and 3). Substituting rock-names for the formulae used earlier, the crystallization and fusion relations derived from fig. $2 b$ may be restated thus:

Fusion of crystalline picrite and peridotite. The first liquid developed would be basaltic. As the temperature was raised, the amount of liquid would increase slowly, without much change in composition, until the temperature reached a value such that the liquid passed the threshold of the liquidus plateau. There would then be a rapid increase in the rate of fusion for slight additional temperature increases, with a corresponding change in liquid composition.

Solution of forsteritic olivine crystals in basaltic magma. Basaltic magmas containing suspended forsteritic olivine crystals would be able to dissolve a considerable proportion of the crystals if the temperature rose above that of the plateau threshold.

Crystallization of picritic liquids. A high proportion of the liquid would crystallize in a small temperature interval, and the forsteritic olivine precipitated would change composition only slightly.

The products of the first two processes would be olivine basalt and picritic magmas. Much higher temperatures would be required to produce liquids of peridotitic or dunitic composition. For instance, the liquidus temperature of the projected picrite $P$, containing 61 modal $\%$ of olivine, lies about $100^{\circ} \mathrm{C}$. above the liquidus plateau on the orthosilicate join (figs. 2 and 3 ). The third process illustrates the crystallization behaviour of magmas rich in dissolved forsterite. These statements may now be compared with current petrological theories.

\section{Discussion.}

'There is general agreement among geologists that basaltic magma is primary' (Turner and Verhoogen, 1951, p. 362). The concept of primary or parent basalts derived from crustal layers of glassy or crystalline basalt (Daly, 1933; Kennedy and Anderson, 1938; Turner and Verhoogen, 1951, p. 363) has played an important role in the evolution of 
petrological theory, but such basalts are not always adequate to explain the succession of differentiates produced in a particular province. Bowen (1928) regarded the peridotite substratum as the source of basaltic magmas, and Hess (1938) suggested that primary peridotite magmas could be derived from the same layer. In several recent publications there have been renewed suggestions that primary basalts are derived. by the selective fusion of crystalline material, probably peridotite, below the Mohorovičić discontinuity, and the available geophysical evidence appears to be compatible with the suggestion (Green and Poldervaart, 1955; Powers, 1955; Wager, 1956). Additional support is offered by the results of controlled thermal experiments on selected basalts, representative of the major basaltic magma types. These led Yoder and Tilley (1957, p. 159) to conclude, tentatively, that all basalts were themselves the product of the same melting process, although they did not specify the material that melted.

If the selective fusion of peridotite gives rise to basaltic magmas only, which is the opinion of most petrologists, there must be some kind of control in operation that prevents the development of magmas more basic than basalt. The composition of the liquid produced by partial fusion of peridotite will depend upon three main factors: the composition of the crystalline peridotite, the temperature of fusion, and the shape of the liquidus surface in the complex basalt-peridotite system.

The first factor may account in part for the variation in composition between saturated tholeiitic magma types and undersilicated alkaline types (Kennedy, 1933; Green and Poldervaart, 1955; Yoder and Tilley, 1957 , p. 159). If there is a limit to the amount of heat available such that the temperature of the magma does not exceed a definite value (Powers, 1955), then the second factor could be the main control. However, the process of partial fusion has occurred frequently (in geological time) and in varied tectonic environments, and it seems remarkable that the temperature should always have risen just high enough to melt out the basaltic fraction. It is more likely that the fusion temperatures have varied from time to time and from place to place, and that the control is effected by the third factor, the shape of the liquidus surface. It has been demonstrated earlier that this could limit the composition of the melted fraction over a considerable temperature interval.

If a range of melting temperatures is admitted, the temperature could occasionally rise high enough to pass the threshold of the plateau on the liquidus surface, if such exists. This would give rise to magmas containing a high proportion of dissolved forsterite. Bowen (1928) believed that 
basaltic liquids never contained more than $12-15 \%$ of olivine in solution, but Drever (1956) has presented evidence that picritic magmas containing up to $25 \%$ of dissolved forsterite may be a widespread and important type. The earlier discussion illustrates how such magmas could develop without the requirement of very high temperatures.

Some of the olivine basalts commonly believed to represent basalt magma plus accumulated olivine could thus represent original magmas. The presence of olivine phenocrysts need not indicate that they accumulated from a parent basaltic magma (Drever and Johnston, 1957; Wyllie, 1958a). Resorption and the development of skeletal forms in olivine phenocrysts could be a reflection of the solution and reprecipitation of considerable amounts of olivine in response to minor temperature fluctuations. The degree of fractionation of early olivine precipitates governs the extent to which a basaltic magma can produce acid derivatives. It is important, therefore, to establish more closely how much of the olivine in specific basalts crystallized in place, and how much was separated from a parent basalt elsewhere. The growth properties of olivine make this a difficult task.

The olivines in many olivine-rich rocks are only slightly zoned (Drever ${ }_{b} 1956$; Drever and Johnston, 1958; Wyllie, 1958a). This fact is generally adduced as evidence that they could not have crystallized in situ from a homogeneous magma, but it has been shown above that a picritic liquid could precipitate a high proportion of forsteritic olivine with very little change in composition.

A platean on a liquidus surface like that illustrated in fig. $2 a$ frequently implies the presence of a metastable region of liquid immiscibility below the surface. The effect of water vapour under pressure could conceivably lower the liquidus temperatures sufficiently for the surface to intersect such a field of immiscibility. This possibility should not be dismissed out of hand. Drever's (1960) discovery of globules in the non-porphyritic zone of a picrite sheet could indicate the former existence of immiscible liquids.

These remarks are sufficient to indicate that if a plateau is present on the liquidus surface of the basalt-peridotite system, several petrological axioms must be critically re-examined. It is desirable to measure the liquidus and solidus temperatures of a suite of rocks with compositions ranging from basalt to picrite, both dry and under hydrothermal conditions, to see whether a plateau does exist in the natural system. Such measurements are not readily made, because of the high temperatures required, and because of difficulties involved in the interpretation 
of quenched liquids rich in olivine. Equipment planned or under construction in this department should cope with the first difficulty, and it is hoped that even with an increase in the proportion of olivine over that present in basalts the original condition of the quenched products can be deduced (cf. Yoder and Tilley, 1956, p. 169).

Acknowledgements. Professors E. F. Osborn and W. Q. Kennedy and Drs. H. I. Drever and P. G. Harris kindly offered critical comments.

\section{References.}

Bowen (N. L.), 1928. The Evolution of the Igneous Rocks. Princeton University Press (new edn, 1956, Dover publications, New York).

__ and Schatrer (J. F.), 1935. Amer. Journ. Sci., vol. 29, p. 151.

—_ and Tutrue (O.F.), 1949. Bull. Geol. Soe. Amer, vol. 60, p. 439.

Brown (G. M.), 1956. Phil. Trans. Roy. Soc., ser. B, vol. 240, p. 1.

DALY (R. A.), 1933. Igneous Rocks and the Depths of the Earth. McGraw-Hill Book Co., New York.

Drever (H. I.), 1952. Medd. Dansk Geol. Forening, vol. 12, p. 227.

- 1956. Medd. Grønland, vol. 137, no. 4.

-1960. Immiscibility in the Picritic Intrusion at Igdlorssuit. Manuscript sub. mitted to 21st Internat. Geol. Congr., Copenhagen.

___ and Johnston (R.), 1957. Trans. Roy. Soc. Edin., vol. 63, p. 289.

—— 1958. Ibid., p. 459.

Green (J.) and Poldervaart (A.), 1955. Geochimica Acta, vol. 7, p. 177.

Harker (A.), 1904. The Tertiary Igneous Rocks of Skye. Mem. Geol. Surv. U.K. - 1909. The Natural History of Igneous Rocks. MacMillan Co., New York.

Hess (H. H.), 1938. Amer. Journ. Sci., vol. 35, p. 321.

-_- 1955. Geol. Soc. Amer. Spec. Paper 62, p. 391.

Kennedy (W. Q.), 1933, Amer. Journ. Sei., vol, 25, p. 239.

- and Anderson (E. M.), 1938. Bull. Volcan., ser. 2, vol. 3, p. 23.

Osborn (E. F.), 1954. Regional Technical Meetings, p. 145. Amer. Iron and Steel Inst., New York.

- Devries (R. C.), Gee (K. G.), and Kraner (H. M.), 1954. Trans. Amer. Inst. Mining Met. Engrs., vol. 200, p. 33.

___ and TAIT (D. B.), 1952. Amer. Journ. Sci., Bowen vol., p. 413.

Powers (H. A.), 1955. Geochimica Acta, vol. 7, p. 77.

Ricker (R. W.), 1952. Phase Equilibria in the Quaternary System CaO-MgO-FeO$\mathrm{SiO}_{2}$. Ph.D. dissertation, College of Miner. Indust., Pennsylvania State University.

Turner (F. J.) and Verhoogen (J.), 1951. Igneous and Metamorphic Petrology. McGraw-Hill Book Co., New York.

VoGT (J. H. L.), 1922. Journ. Geol., Chicago, vol. 30, p. 659.

WAGER (L. R.), 1956. Geochimica Acta, vol. 9, p. 217.

Wyllie (P. J.), 1958a. Experimental and Petrological Investigations of Some Magmatic Phenomena. $\mathrm{Ph} . \mathrm{D}$. thesis, University of St. Andrews. 1958b. Trans. Amer. Geophys. Union, vol. 39, p. 536.

YODER (H. S.) and Tilley (C. E.), 1956. Carnegie Inst. Washington Year Book 55, p. 169.

___ 1957. Carnegie Inst. Washington Year Book 56, p. 156. 